\title{
THE MODERN STATUS OF NORMATIVELY-LEGISLATIVE REGULATION OF TAX CONTROL IN UKRAINE AND PROPOSALS FOR ITS IMPROVEMENT
}

\section{Puhalsky Vadym ${ }^{1}$}

DOI: http://dx.doi.org/10.30525/978-9934-571-28-2_23

\begin{abstract}
Among the main tasks of the State fiscal service of Ukraine, the systematic control over compliance with tax discipline by economic entities is taking place. The decisive importance here is the adoption of relevant laws and regulations on tax control in Ukraine, which must be harmonized with European norms and be perfect and stable in European integration. The imperfection of the current legislation in the area of tax control in Ukraine is evidenced by its frequent changes and amendments, which have a negative impact for business well as for regulatory bodies.

The purpose of the work is to study the current state of regulatory and legislative regulation of tax control in Ukraine and to develop scientifically substantiated theoretical positions on this basis on the directions of its improvement in order to increase its effectiveness.

It was necessary to solve the following tasks to achieve the goal: to carry out meaningful and definitive analysis of the terms of the legislation, the legal act; to identify the features, to generalize the legal regulation of tax control in Ukraine and to substantiate its shortcomings; to propose directions for improvement of the regulatory and legislative regulation of tax control in Ukraine in order to eliminate flaws and increase the effectiveness of its conduct.

In accordance with the goals and objectives subject of the article is theoretical and methodological principles of analysis and improvement of regulatory and legislative regulation of tax control in Ukraine in order to increase its efficiency.

In the process of scientific research, the methods of theoretical generalization and comparison regarding the development of the conceptual apparatus in the field of regulatory and legislative regulation in general and tax control in Ukraine in particular were used.
\end{abstract}

\footnotetext{
${ }^{1}$ Candidate of Economic Sciences, Associate Professor, Khmelnitsky National University, Ukraine
} 


\section{Introduction}

An important functioning condition of tax control in Ukraine is the favorable and detailed regulatory and legislative regulation of the procedure for its implementation, which, firstly, should be stable, and secondly, mutually consistent with other norms of legislation, thirdly - perfect, fourthly - detailed. These characteristics are important from the point of view of avoiding opaque inspection schemes, organization and implementation of this direction of control.

Recent research and publications analysis. Problems of the tax control regulation were considered in the works of domestic scientists- T. M. Kravtsova, M. P. Kucheryavenko, D. V. Reva and in the works of foreign scientists A. V. Bryzgalin, E. Yu. Grachova, I. I. Kucherov, A. M. Ukraintseva and others.

There is chapter 5 "Tax Control" in the Tax Code of Ukraine (TCU) that is devoted to the tax control, which describes the interpretation of tax control, defines the powers of state authorities and sets out the methods of tax control. However, it is worth to note, that Ukraine has no special law regulating the mechanism of tax control, clearly defining the types, forms, methods, and instruments for its implementation. In this regard, it is important to analyze the current legislation of Ukraine that regulates tax control procedures in order to eliminate the fuzziness of the regulatory control of tax control in Ukraine.

The purpose of the article is to develop scientifically substantiated theoretical positions regarding the directions of improving the regulatory and legal regulation of tax control in Ukraine.

\section{The main research material}

The need to improve the legal regulation of tax control is conditioned by the imperfection of tax legislation, its constant changes (about 100 changes in the TCU for the period from 02.12.2010 to 01.01.2017) do not contribute to the creation of a stable tax system, therefore, and also, for a number of other reasons, there are preconditions for ambiguous interpretation of tax legislation, which leads to tax evasion and the implementation of various tax offenses on the part of both individuals and legal entities, and it makes the supervisory authorities to make decision not in favor of taxpayers. It is appropriate to note that the TCU established that the principle of the tax legislation of Ukraine is the principle of stability (Article 4.1.9, Article 
4), which means that "changes to any elements of taxes and fees can not be made later than six months before the start of a new budget period, in which new rules and rates will apply. Taxes and fees, their rates, as well as tax breaks can not be changed during the budget year" [1]. However, this rule of law is not fulfilled; changes are made without taking into account the above law norm.

The analysis of TCU in the part of tax control, shows that Art. 19 "Functions of controlling bodies" of Section I "General Provisions" was changed and supplemented 20 times, Art. 20 "Rights of controlling bodies" 12 times, Art. 21 "Responsibilities and responsibilities of officials of controlling bodies" - 5 times, Art. 41 "Supervisory authorities and penalties" Chapter $1-5$ times, Art. 61 "Definition of tax control and powers of state authorities on its implementation" of Chapter 5 "Tax control" - 4 times, Art. 62 "Methods of tax control" - 1 time [1].

First of all, we will examine the content of some definitions, namely: legislation, normative legal act. The "legislation" term is often referred to in regulatory legal acts of Ukraine. In the Basic Law of Ukraine - the Constitution, the term "legislation" is used in art. 9 "national legislation", in art. 19 "provided by law", in art. 118 "Other legislative acts", in Section XV "Transitional Provisions" "in accordance with the current legislation". However, in the Constitution of Ukraine there is no interpretation of the definition of "legislation", which, of course, leads to a different interpretation of this term [2].

The essence of the term "legislation" is given in the decision of the Constitutional Court of Ukraine in the case of the constitutional petition of the Kyiv City Council of Trade Unions concerning the official interpretation of part three of Article 21 of the Code of Labor Laws of Ukraine (the case on the interpretation of the term "legislation") of 09.07.1998, No. 12-p / 98 The term "legislation" is widely used in the legal system, mainly as a set of laws and other normative legal acts that regulate one or another sphere of social relations and are sources of a certain field of law. In laws, depending on the importance and specificity of regulated social relations, this term is used in different meanings: in some, only laws are meant; in others, first of all codification, the term "legislation" includes both laws and other acts of the Verkhovna Rada of Ukraine and acts of the President of Ukraine, the Cabinet of Ministers of Ukraine, and in some cases also the normative legal acts of central executive authorities [3]. 
Hence, "legislation" can be viewed in a narrow and broad sense. In the narrower sense, the term "legislation" refers to the system of laws of Ukraine, which is established by the Verkhovna Rada of Ukraine as the sole legislative authority. This category also includes international treaties agreed upon by the Verkhovna Rada of Ukraine through the adoption of a law on ratification of the relevant treaty (Article 9 of the Constitution of Ukraine) [2].

In the broad sense, the term "legislation" means a system of laws and other normative acts adopted by the Verkhovna Rada of Ukraine and the highest organs of the executive power - decrees of the President of Ukraine, decrees and regulations of the Cabinet of Ministers of Ukraine, decrees of the President of Ukraine, decrees and regulations of the Cabinet of Ministers of Ukraine, as well as regulations of ministries and departments, city councils and local state administrations

Thus, the notion of "legislation" on the one hand is one of the main methods of the state's exercise of its functions through the laws issuance by the state authorities, and on the other hand, as a set of existing legal norms regulating social relations through laws, by laws statutory acts (decrees, decrees, decrees, orders, instructions, etc.). With regard to tax legislation, the SFS gives the following interpretation: tax legislation - legislation that establishes and regulates tax collection and tax payments, and in relation to the tax law, the SFS considers it as a legal act of the highest legislative body, which obliges the legal individuals and citizens to pay to the budget payments in the form of taxes in a certain amount and in precisely specified terms [4].

The following term used in reference to the practice of tax control is a normative act. In the legal terminology we find: a nominative act is an official written document, which establishes, amends or abolishes the rules of law, is general or local in nature and is repeatedly applied by the authorized state or other body within its competence. The normative acts include: regulations, rules, instructions, decisions, etc., which are entered into force by order [5].

In the legal encyclopedia, the normative act is an imperious order of state bodies, which establishes, amends or abolishes the rules of law (law, code, resolution, instruction, etc.). It is one of the main sources of law of the modern state, the predominant form [6].

In the dictionary of business terms, a normative act is understood as law, a code, a regulation, instruction, and other imperious order of state bodies, which establishes, modifies or abolishes the rules of law. The prescriptions of normative legal acts have a general character and are aimed at regulation [7]. 
Legal act - an official written document adopted by the competent authority of the state, in which the legal norms are formulated [4].

State legal regulation of tax control is necessary in order to create uniform rules, approaches to the organization, conduct and adoption of the decision-making on its results.

The foreign literature distinguishes three main elements in the system of legal regulation of tax control:

- legal norms, through which tax authorities receive the information necessary for tax control both from the taxpayer and from third parties;

- legal norms, which give the tax authorities the necessary powers for tax control and execution of tax duty on a compulsory basis;

- legal norms that establish the rights and guarantees of the taxpayer [8].

In Ukrainian legislation in the area of tax control, the above elements are grouped into TCU.

In addition, foreign researchers divided all laws that may be subject to tax control into three groups.

- general laws that define the powers of the tax authority, as well as the rights and obligations of the taxpayer in the part of tax control in respect of all taxes established in the respective state - in this case it may be an act that codifies most of the tax the legislation of the state, including the regulation of tax control, or a special law that combines the rules for the implementation of tax control;

- special laws, regulating the legal status of the tax authority and the taxpayer in relation to the implementation of tax control in terms of paying a separate tax (eg VAT);

- other non-tax laws, including provisions relating to tax control [8].

The legal and regulatory basis for tax control in Ukraine includes two levels (Figure 1):

Ukraine's integration processes in the international community are accompanied by the introduction of the practice of tax control of international standards, the harmonization of national and international law, and the use of best international practice. However, the introduction of international standards is a complicated and ambiguous process, due to its own problems with the state. Among the international instruments that relate to tax control, it is necessary to highlight the Lima Declaration of the Principles of Control (1977) INTOSAI (International Organization of Supreme Audit Institutions acting under the auspices of the United Nations or its spe- 


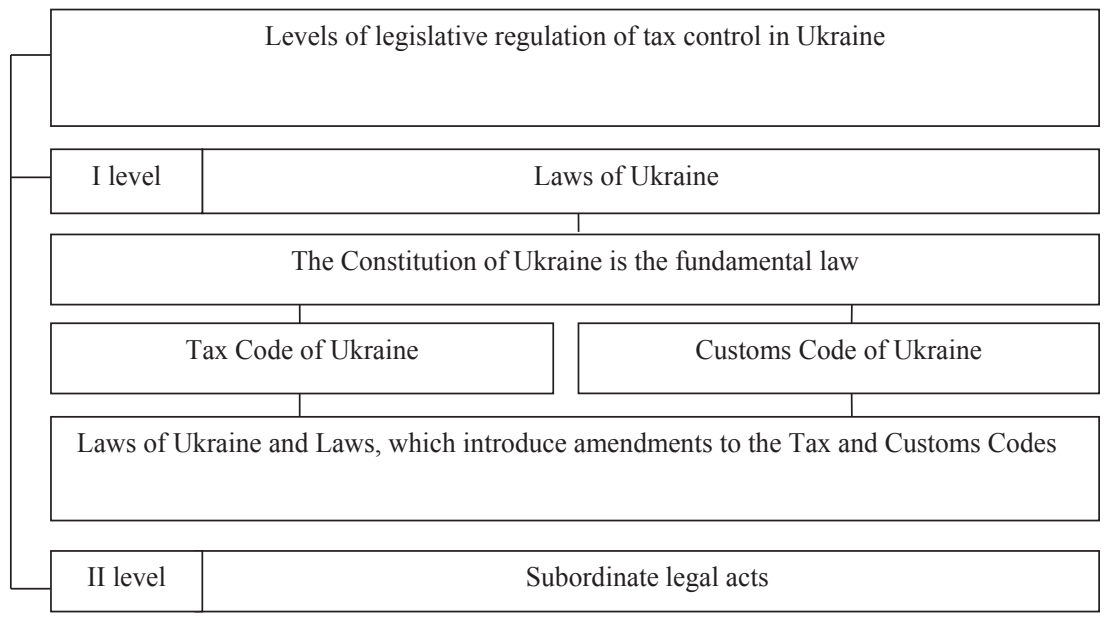

Fig. 1. Levels of legislative regulation of tax control in Ukraine

cialized agencies, which plays the main role in the audit of public finances and the development of transparent financial systems and the accountability of governments of 192 countries, within which there are regional organizations), the norms of which are recognized as a benchmark for assessing the level of organization of financial control [9].

International tax acts should include international agreements on the avoidance of double taxation, which are the most important source of international tax law (an integral part of the legislation on taxes and fees). In its recommendations, the UN explicitly states that the conclusion of bilateral agreements on the avoidance of double taxation on income and property is by far the most optimal option for solving international tax problems [9]. International tax agreements, the consent of which is granted by the Verkhovna Rada of Ukraine, are more forceful than national tax laws (Section 3.2, Article 3 of the Tax Code) [1].

It is appropriate to pay attention to such a direction of tax control as control of the keeping of the principle of "elongated hand". It is the area of tax control that has rapidly started to develop in Ukraine since 2013, due to the adoption of a number of legal acts.

The main international acts that establish and explain the methodology, procedure, procedures and peculiarities of the implementation of the reg- 
ulation and supervision of compliance with the principle of an "elongated hand" are:

- OECD Transfer Pricing Guidelines for Transnational Companies and Tax Services (OECD Transfer Pricing Guidelines for Multinational Enterprises and Tax Administrations, Paris, 22 July 2010);

- Modular (typical) OECD Convention on Income and Capital Tax (Model Tax Convention on Income and on Capital: Condensed Version, OECD, Paris, 22 July 2010; Model Tax Convention on Income and Capital: Full Version (as it read on 22 July 2010) OECD (2012), Paris);

- Methodological recommendations on the development of legislation on transfer pricing in order to harmonize the approach used (OECD Transfer Pricing Leasing Regulation - A Recommended Approach, Paris, June 2011).

Therefore, the above-mentioned normative acts are an integral part of the tax control regulation.

As part of the first level of legal regulation of tax control in Ukraine, we have identified the Basic Law - the Constitution of Ukraine, which consolidates the social and state structure of the country, the functions of state authorities, the basic rights and duties of citizens. One of the constitutional duties of citizens of Ukraine is the obligation of each to pay taxes and fees in the order and amounts established by law, as well as annually submit to the tax inspectorates at the place of residence the declaration of their property status and income for the last year in the manner prescribed by law (Article 67 of the Constitution of Ukraine) [2].

The Constitution as the main source of tax legislation contains the legal principles governing the normative regulation of central and local taxes and are the basis for procedural tax legislation; establishes legal bases of tax activity of the state and competence of central and local authorities in the field of tax relations. The Constitution of Ukraine explicitly refers to the legal form of the introduction of the tax, in particular, in paragraph 1 of part two of Article 92 it is determined that only the laws of Ukraine set the tax system, taxes and fees. In Art. 98 of the Constitution of Ukraine states that the Accounting Chamber carries out control on behalf of the Verkhovna Rada of Ukraine for the receipt of funds into the State Budget of Ukraine and their use [2].

The state budget filling, realization of tasks and functions of the state directly depends on the effective performance of all subjects of the tax legislation of the tax duty. The role of the SFS of Ukraine in this process is key because they are required by the rules of the current legislation to monitor 
their timeliness and completeness of payment of taxes, fees (other mandatory payments).

The implementation of this control is primarily aimed at creating conditions for the voluntary fulfillment of the constitutional duty for the taxpayer to pay the corresponding amounts to the budget and reduce the cases of coercive measures. Therefore, one of the main tasks of tax authorities in the process of declaration is the prompt provision of information and consulting services to the citizens.

The constitutional provisions on tax control have their particulars in the TCU, which serves as the main legislative act in the field of tax control. According to Art. 3 "Tax Legislation" of the Tax Code specifies that the tax law of Ukraine consists of the Constitution of Ukraine, the Tax Code, the Customs Code and other laws on customs matters and other laws on customs matters in terms of regulating legal relations arising from relocation goods through the customs border of Ukraine; current international treaties, the consent of which is binding on the Verkhovna Rada of Ukraine; normative legal acts adopted on the basis and on the basis of TCU and laws on customs matters, decisions of the Verkhovna Rada of Ukraine, local self-government bodies on local taxes and fees, adopted under the rules of the TCU [1].

The content, authority of the bodies and methods of tax control are presented in Chapter 5 "Tax Control" of the TCU, which includes two articles, each of which consists of 3 and 4 sub-paragraphs, respectively. Chapter 8 "Inspections" defines the types and regulates the procedure for conducting documentary, factual checks, examinations and generalization of the results of inspections. Although chapter 5 of the TCU is intended to detail the tax control, certain rules that should be included in this chapter are found in other chapters and articles, in addition, there is no interpretation of the types, forms, principles, methods, tools of its implementation, ie not made the only concept of tax control in Ukraine, which impedes the formation and development of an integrated system of tax control.

Prior to the adoption of the Tax Code, tax control was regulated by a number of subordinate legal acts (instructions, orders, methodological recommendations, etc. of the State Tax Service of Ukraine). TCU has, to a certain extent, generalized the procedures of mutual relations between tax authorities and taxpayers during the conduct of tax audits.

Some articles focus on the application of customs legislation to tax control (inclusion in the collection of taxes and duties - a special mandatory 
payment, which is part of the tax system of Ukraine, is made when crossing the customs border of Ukraine and is regulated by customs legislation, the imposition of the value-added tax and excise tax upon crossing the customs border of Ukraine, which is regulated, including by the customs legislation). In this regard, tax legislation regulates the collection of such payments on the of financial and administrative law. In general, the Customs Code of Ukraine regulates the external economic activity of business entities, along with which separate articles $(302,303,345-355,467,474,475,485)$ relate to tax audits of subjects of foreign economic activity [11].

The Tax and Customs Codes of Ukraine are constantly being amended by a number of laws of Ukraine. So the PKU is supplemented by Art. $19^{1}$ Functions of the bodies of the State Tax Service in accordance with the Law of Ukraine "On Amendments to the Tax Code of Ukraine regarding the State Tax Service and in connection with the conduct of administrative reform in Ukraine" dated 05.07.2012, No. 5083-VI [12]. The Law of Ukraine "On Amendments to the Tax Code of Ukraine regarding Improvement of the Investment Climate in Ukraine" of 21.12.2016, No. 1797-VIII [13] entrusted new responsibilities to officials of the controlling bodies. According to Art. $19^{1}$ TCU functions of state tax inspections defined: the implementation of service-servicing of taxpayers; realization of registration and accounting of taxes on single tax payers and taxpayers, taxation objects and objects related to taxation; formation and maintenance of the State Register of Natural Persons - Taxpayers, the Single Data Bank on Taxpayers - legal entities, registries, which are entrusted by law to the controlling bodies; performance of other functions of service of taxpayers defined by law. This law of Ukraine does not provide for the right to conduct tax and documentary inspections of taxpayers by tax inspectors. That is, the corresponding changes are made in Art. 191 $19^{2}, 19^{3}$, distinguishing between the functions of the controlling bodies and the Ministry of Finance of Ukraine.

In order to avoid the tax liabilities minimization and withdrawal of profits outside Ukraine, the Law of Ukraine "On Amendments to the Tax Code of Ukraine on Improving Tax Control of Transfer Pricing" was adopted on January 28, 2014, No. 72-VIII [14]. Tax control over transfer pricing provides for adjusting taxpayer's tax liabilities to the level of tax liabilities calculated on condition that the commercial and / or financial conditions of the co-controlled transactions are commensurate with the commercial and / or financial conditions that occurred during the carrying out comparable 
operations provided for in this Article, the parties of which are not related parties. For a deeper understanding of the content of this law of Ukraine and the relevant actions of the tax control body of the DFSU by its letter of 07.07.2015, No. 24525/7 / 99-99-22-01-02-17 “On Tax Control of Transfer Pricing in the Communications Together with the introduction of amendments to the Tax Code of Ukraine, details of certain issues related to the application of tax legislation on the control of transfer pricing [15].

The second level of legislative regulation of tax control in Ukraine is represented by bylaws, which include the message of the President of Ukraine, the CMU Orders, orders of the SFSU, etc.

Among subordinate regulatory acts, first of all, it is necessary to include the message of the President of Ukraine, which regularly raises issues of improving tax administration and tax control. This group of legal regulation of the tax control procedures includes both subordinate regulatory acts of the Cabinet of Ministers of Ukraine and the Ministry of Finance, which are required for execution by the tax authorities. Here are some of them. First of all, they include the "Regulation on the State Fiscal Service of Ukraine" dated 21/05/2014, No. 236, which defines the tasks and rights of this service [16].

Order of the MFU "On Approval of Amendments to the Procedure for Submitting Tax Notices to Taxpayers" dated May 23, 2016 No. 498 [17], which, in particular, supplemented the types of liability of taxpayers, which are subject to tax authorities by the controlling bodies message-decision, new types of penal (financial) sanctions (fines), introduction of a tax notification-a decision for the use by the controlling bodies of sanctions (fines) imposed by the TCU (including on established violations CCU) application which are not directly related to the definition of tax liabilities. In particular, these are sanctions for non-submission or late submission of tax returns, for violating the established deadlines for storing documents, failure to submit or violate the timing of submission of tax information, the order of reckoning (registration) in supervisory bodies.

By order of the MFU "On Approval of the Procedure for Inspection on Taxpayer Compliance with the Extension of the Principle of "Elongated Hand" dated March 10, 2016 No. 344 [18] it was determined that the form of tax control is to establish the conformity of the conditions of control operations with the principle of an "elongated hand" etc.

In order to properly organize the work on the holding and implementation of documentary checks results on compliance with the requirements 
of the legislation of Ukraine on the state customs business, an order was issued to the SFSU "On approval of methodological recommendations on the interaction between the divisions of the State Fiscal Service in the Organization, holding and implementation of documentary materials inspections of compliance with the requirements of the Ukrainian law on state customs issues" dated October 12, 2016, No. 856 [19].

In accordance with clause 73.5 of Art. $73 \mathrm{TCU}$, in order to introduce a unified procedure for organizing work on the exchange and processing of tax information in the implementation of tax control, the submission of requests for the conduction of counter checks, as well as the design, transfer and accumulation of materials for counter-checks, the SFS authorities adopted an order of the SFSU "On approval of methodological recommendations on organizing and conducting organs of the state fiscal service of counter-inspections, exchange of tax information in the course of tax control "dated July 17, 2015, No. 511 State fiscal and service of Ukraine [20].

Legal acts of state authorities and local self-government bodies in the area of taxes and fees that are taken within their powers do not directly regulate tax control procedures, but they are used by tax authorities when verifying the correctness and timeliness of calculating and paying local taxes.. In Khmelnytsky, in 2018, the following local taxes and duties were set: personal income tax (tax rate 18\%), profit tax on enterprises and organizations belonging to municipal property of the city (tax rate 18\%), tax on immovable property other than land, land tax, transport, tourist tax (rate $1 \%$ of the cost of living), excise tax on realization by retailers of excisable goods, payment for the provision of others administrative services (the size of the installment fee are enrolled by various departments (State Migration Service, State Statistics Service, State Registry Service, Ministry of Internal Affairs, etc.), and their monthly revenues are not constant, a single tax (depending on the group to which entrepreneurs belong) and a single social contribution ( the rate is $22 \%$ ) [21].

In the context of these taxes and fees, control procedures should be carried out, however, due to the moratorium on tax inspections for 2015-2017, the controlling bodies inspect enterprises, institutions, organizations and individuals entrepreneurs with an income volume of up to UAH 20 million for the previous calendar year exclusively: with the permission of the Cabinet of Ministers; at the request of the entity for its verification; in accordance with the decision (requirements) of the Criminal Procedure Code of Ukraine. 
It should be noted that within this article we have not examined and analyzed all the regulatory and legislative acts of tax control, since their number is significant and gradually changing.

\section{Conclusions}

The study of regulatory and legislative regulation in the field of tax control allowed some conclusions to be drawn and suggested practical recommendations for its improvement, namely: firstly, changes and additions are frequently made to the TCU, especially their number increased in 2016., which indicates a large number of ambiguous norms that allow regulatory authorities to manipulate legislation, make decisions not in favor of taxpayers; Second, Chapter 5 of the TCU is designed to precisely detail the tax control of certain rules that should be included in this chapter in other chapters and articles, in addition, there are no interpretations of the types, forms, principles, methods, tools of its implementation, the procedures of the organ tion and implementation of tax control, ie, the unified concept of tax control in Ukraine has not been developed, which impedes the formation and development of an integrated system of tax control. In our opinion, they need to be presented in a complex way in the TCU as a separate section "Conceptual bases of tax control"; Third, the SFSU sends letters of various kinds, develops methodological recommendations that specify the procedure for the implementation of tax control, which is not covered in the TCU, that is, such detail should also be contained in the TCU, this information should be owned by taxpayers in order to unambiguously interpret the rules of the current tax law, Fourth, it is necessary to allocate authorities of bodies in the field of tax control, as they are contained only in the title of Art. $61 \mathrm{TCU}$, fifth, to determine the cases when the results of tax control are considered invalid because of gross violation of the current legislation during its conduct. Thus, the development and proposed recommendations will promote the orderly and unambiguous regulatory framework of tax control, will help to make opaque audit schemes impossible and improve the organization and implementation of tax control in Ukraine.

\section{References:}

1. Podatkovyi kodeks Ukrainy vid 02. 12. 2010. № 2755-VI (red. 07.09.2017) [Tax Code of Ukraine dated 02. 12. 2010. № 2755-VI (as amended on 07.09.2017)]. Available at: http://zakon5.rada.gov.ua/laws/show/2755-17.

2. Konstytutsiya Ukrainy vid 28. 06. 1996. № 254k/96-VR (red. 30.09.2016) [The Constitution of Ukraine dated 28.06.1996. № 254k/96-VR (as amended on 


\section{Puhalsky Vadym}

30.09.2016) Available at: http://zakon3.rada.gov.ua/laws/show/254\%D0\%BA/96$\% \mathrm{D} 0 \% \mathrm{~B} 2 \% \mathrm{D} 1 \% 80$.

3.. Rishennia Konstytutsiinoho Sudu Ukrainy u spravi za konstytutsiinym zvernenniam Kyivskoi miskoi rady profesiinykh spilok shchodo ofitsiinoho tlumachennia chastyny tretoi statti 21 Kodeksu zakoniv pro pratsiu Ukrainy (sprava pro tlumachennia terminu “zakonodavstvo") vid 09.07.1998, №. 12-rp / 98. [The judgement of the Constitutional Court of Ukraine in the case of the constitutional appeal of the Kyiv City Council of Trade Unions concerning the official interpretation of part three of Article 21 of the Code of Labor Laws of Ukraine (case on the interpretation of the term "legislation")] since 09.07.1998, No. 12-rp / 98. Available at: http://zakon2.rada.gov.ua/laws/show/v012p710-98.

4. Slovnyk osnovnykh terminiv. Derzhavna fiskalna sluzhba. Ofitsiinyi portal. [Basic terms glossary. State Fiscal Service. Official portal]. Available at: http://sfs.gov.ua/korisni-posilannya/slovnik.

5. Yurydychnyi terminolohichnyi slovnyk [Legal terminology dictionary]. Available at: http://www.marazm.org.ua/document/termin/index.php?file $=\% \mathrm{C} 7 \% \mathrm{E} 0 \% \mathrm{EA} \% \mathrm{EE} \% \mathrm{ED} . \mathrm{txt}$

6. Yurydychna entsyklopediia v 6 t. (2002) [Legal encyclopedia in 6 volumes]. Edit: Yu.S. Shemshuchenko, etc. K. : "Ukr. Entsykl.”, 736 p.

7. Slovnyk biznes-terminiv [Business terms glossary]. Available at: https://dic.academic.ru/dic.nsf/dic economic law/9066/\%D0\%9D\%D0\%9E\%D0

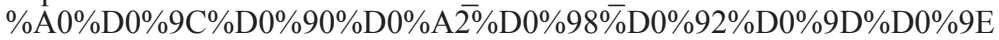

8. Kylynkarova E. V. (2017) Nalohovoe pravo dlia zarubezhnыkh stran : uchebnyk dlia bakalavrata y mahystratury [Tax law for foreign countries: a textbook for undergraduate and postgraduate studies] M. Yurait, $318 \mathrm{p}$.

9. Limska deklaratsiia kerivnykh pryntsypiv kontroliu (1977 p.) INTOSAI [The Lima Declaration of Guidelines on Auditing Precepts]. Available at: http://zakon2.rada.gov.ua/laws/show/604_001.

10. Borovyk S. (1991) Suchasna praktyka zastosuvannia uhod po unyknenniu podviinoho opodatkuvannia dokhodiv maina [Modern practice of agreements to avoid double taxation of property income] Zovnishnia torhivlia. No. 1-2.

11. Mytnyi kodeks Ukrainy vid 13.03.2012 r. № 4495-VI (redaktsiia vid 03.12.2017 r.) [Customs Code of Ukraine dated March 13, 2012 No. 4495-VI (as amended on 03.12.2017)]. Available at: http://zakon3.rada.gov.ua/laws/ show/4495-17.

12. Zakon Ukrainy "Pro vnesennia zmin do Podatkovoho kodeksu Ukrainy shchodo der-zhavnoi podatkovoi sluzhby ta $\mathrm{u}$ zviazku z provedenniam administratyvnoi reformy v Ukraini” vid 05.07.2012 r. № 5083-VI [Law of Ukraine “On Amendments to the Tax Code of Ukraine regarding the State Tax Service and in connection with the conduct of administrative reform in Ukraine" dated 05.07.2012, No. 5083-VI]. Available at: http://zakon3.rada.gov.ua/laws/show/5083-17.

13. Zakon Ukrainy "Pro vnesennia zmin do Podatkovoho kodeksu Ukrainy shchodo pok-rashchennia investytsiinoho klimatu v Ukraini" vid 21.12.2016 r. № 1797-VIII [The Law of Ukraine "On Amendments to the Tax Code of Ukraine for the Promotion of the Investment Climate in Ukraine" dated December 21, 2016, No. 1797-VIII]. Available at: http://zakon3.rada.gov.ua/laws/show/1797-19. 


\section{The modern status of normatively-legislative regulation of tax control...}

14. Zakon Ukrainy "Pro vnesennia zmin do Podatkovoho kodeksu Ukrainy shchodo udo-skonalennia podatkovoho kontroliu za transfertnym tsinoutvorenniam” vid 28.12.2014 r. № 72-VIII [The Law of Ukraine “On Amendments to the Tax Code of Ukraine for the Adoption of the Tax Control for Transfer Pricing" dated 28.12.2014, No. 72-VIII]. Available at: http://zakon2.rada.gov.ua/laws/show/72-19.

15. Lyst DFSU "Pro podatkovyi kontrol za transfertnym tsinoutvorenniam u zviazku iz vnesenniam zmin do Podatkovoho kodeksu Ukrainy" [Letter to the SFSU "On Tax Control of Transfer Pricing in Connection with the Amendment to the Tax Code of Ukraine"']. Available at: https://www.pard.ua/uk/news/3549-dfsu-rozyasnyuye-deyaki-pytannya-shchodo/.

16. Postanova KMU "Polozhennia pro Derzhavnu fiskalnu sluzhbu Ukrainy" vid 21.05.2014 r. № 23 [Elektronnyi resurs]. - Rezhym dostupu: http://zakon3.rada.gov.ua/ laws/show/236-2014-\%D0\%BF.

17. Nakaz MFU "Pro zatverdzhennia Zmin do Poriadku nadislannia kontroliuiuchymy orhanamy podatkovykh povidomlen-rishen platnykam podatkiv" vid 23.05.2016 r. № 498 [Order of the MFU "On Approval of Amendments to the Procedure for Submitting Tax Authorities to Taxpayers by the Supervisory Bodies" dated May 23, 2016, No. 498]. Available at: http://zakon3.rada.gov.ua/laws/show/ z0846-16.

18. Nakaz MFU "Pro zatverdzhennia Poriadku provedennia perevirky z pytan do-trymannia platnykom podatkiv pryntsypu "vytiahnutoi ruky" vid 10.03.2016 r. № 344 [Order of the MFU “On approval of the procedure for conducting an audit of the issues of keeping a taxpayer with the principle of" extended hand "from March 10, 2016, No. 344]. Available at: http://zakon2.rada.gov.ua/laws/show/z0497-16.

19. Nakaz DFSU "Pro zatverdzhennia Metodychnykh rekomendatsii shchodo poriadku vza-yemodii mizh pidrozdilamy orhaniv derzhavnoi fiskalnoi sluzhby pry orhanizatsii, provedenni ta realizatsii materialiv dokumentalnykh perevirok dotrymannia vymoh zakonodavstva Ukrayiny z pytan derzhavnoi mytnoi spravy" vid 12.10.2016 r. № 856 [Order of the SSSU “On Approval of Methodological Recommendations on the Procedure for Interaction Between Subdivisions of the State Fiscal Service Bodies in the Organization, Implementation and Implementation of Materials for Documentary Inspections of Compliance with the Laws of Ukraine on State Customs Matters" dated October 12, 2016, No. 856]. Available at: http://sfs.gov.ua/yuridichnim-osobam/podatkoviy-kontrol/nakazi/69970.html.

20. Nakaz DFSU "Pro zatverdzhennia Metodychnykh rekomendatsii shchodo orhanizatsii ta provedennia orhanamy derzhavnoi fiskalnoi sluzhby zustrichnykh zvirok, obminu podatkovoiu informatsiieiu pry zdiisnenni podatkovoho kontroliu” vid 17.07.2015 r № 511 [Order of SSSU “On Approval of Methodological Recommendations on the Organization and Conduct by the Bodies of the State Fiscal Service of Combat Inspections, the Exchange of Tax Information in the Implementation of Tax Control" dated July 17, 2015 No. 511]. Available at: http://sfs.gov.ua/yuridichnim-osobam/podatkoviy-kontrol/nakazi/print-66306.html.

21. Pro proekt biudzhetu mista Khmelnytskoho na 2018 rik [About the budget of the city of Khmelnitsky for 2018]. Available at: http://khmelnytsky.com/index. php?option $=$ com_content $\&$ view $=$ article $\& i d=40205 \% 3 \mathrm{~A}-2018-\&$ catid $=330 \% 3 \mathrm{~A} 2$ 011-09-30-07-09-51\&Itemid=251 